\title{
Sesquiterpene Lactones and other Chemical Constituents of Mikania hoehnei R.
}

\author{
Juliana S. Chaves and Dionéia C. R. de Oliveira* \\ Departamento de Física e Química. Faculdade de Ciências Farmacêuticas de Ribeirão Preto, Universidade de \\ São Paulo, Via do Café s/n, 14040 903, Ribeirão Preto-SP, Brazil
}

\begin{abstract}
O estudo fitoquímico de Mikania hoehnei conduziu ao isolamento e à identificação de acetato de lupeol, estigmasterol, $\beta$-sitosterol, campesterol, 3-O- $\beta$-D-glicopiranosil estigmasterol, 3-O- $\beta$-Dglicopiranosil sitosterol, 2,6-dimetoxibenzoato de benzila, luteolina, caempferol e duas lactonas sesquiterpênicas diidrocostuslactona e $8 \beta$-hidroxizaluzanina D. Estas substâncias foram identificadas com base na análise dos espectros de IV, EM e RMN de ${ }^{1} \mathrm{H} \mathrm{e}{ }^{13} \mathrm{C}$ e os dados foram comparados com os descritos na literatura.

Phytochemical study of Mikania hoehnei yielded lupeyl acetate, stigmasterol, $\beta$-sitosterol, campesterol, $\beta$-sitosteryl glucopyranoside, stigmasteryl glucopyranoside, benzil 2,6dimethoxybenzoate, luteolin, kaempferol and two sesquiterpene lactones: dehydrocostuslactone and $8 \beta$-hydroxyzaluzanin D. IR, ${ }^{1} \mathrm{H}$ and ${ }^{13} \mathrm{C}$ NMR and MS spectroscopic analyses and comparisons with previously reported data were used for the identification of these compounds.
\end{abstract}

Keywords: Mikania hoehnei, Asteraceae, guaianolides, flavonoids

\section{Introduction}

Mikania hoehnei B. Robinson, first described by B. Robinson in 1934, is an endemic vine found in Brazil from Rio de Janeiro to Santa Catarina. ${ }^{1,2}$ Only one report has appeared dealing with the terpenoids of M. hoehnei, ${ }^{3}$ in which the presence of lupeol and stigmasterol was indicated. We selected the entire plant for phytochemical investigation as part of our studies on members of the Eupatorieae. $^{4-6}$

The genus Mikania has undergone taxonomic studies, where morphologic information was considered ${ }^{1,7-9}$ and an evaluation of the existence of correlations between the terpenoid chemistry and the phylogeny of those species was done. ${ }^{10,11}$ Mikania hoehnei B. Robinson belongs to the subtribe Mikaniinae, section Mikania (L.) Willd. (Holmes, private communication) and phytochemical investigation of the whole plant led to the isolation of two sesquiterpene lactones. Their structures were proposed on the basis of spectroscopic data and comparisons of the attributed signals with previously reported data. ${ }^{12-17}$

Although the occurrence of sesquiterpene lactones is common in species of Mikania, guaianolides have been

\footnotetext{
* e-mail: drolivei@usp.br
}

found in only 3 of the 46 species studied so far, e.g. in $M$. vitifolia, ${ }^{18}$ M. haenkeana ${ }^{19}$ and $M$. mendocina. ${ }^{20}$ There also seems to be a remarkable difference between the compounds identified in M. hoehnei and those reported for other Mikania species.

\section{Experimental}

\section{General}

The IR spectra were obtained on $\mathrm{NaCl}$ film in a Perkin Elmer model 1420 spectrophotometer. ${ }^{1} \mathrm{H}$ NMR (300 MHz) and ${ }^{13} \mathrm{C}$ NMR $(75 \mathrm{MHz})$ spectra were recorded on a Bruker DPX 300 in $\mathrm{CDCl}_{3}$ with TMS as internal standard. EIMS was obtained at $70 \mathrm{eV}$ on HP 5988-A. Prep. TLC was carried out on Si gel PF-254 (Merck), CC on Si gel 60 (0.063 a 0.200) (Merck) and VLC on Si gel 60 H (0.005 - 0.045) (Merck).

\section{Plant material}

Mikania hoehnei B. Robinson was collected in Restinga de Maricá, Rio de Janeiro, RJ, Brazil, in July 1996, and identified by Professor Dr. Janie G. Silva (Instituto de Biologia da Universidade Federal Fluminense, Rio de Janeiro). A voucher specimen (SPFR 04309) was deposited 
in the herbarium of the Department of Biology, FFCLRP/ USP and was used for the authentication of the species.

\section{Extraction and fractionation}

Dried and powdered whole M. hoehnei plants ( $2.8 \mathrm{~kg})$ were exhaustively extracted at room temperature with hexane, ethyl acetate and ethanol in successive phases. Evaporation of solvents under reduced pressure furnished $64.0 \mathrm{~g}, 25.0 \mathrm{~g}$ and $35.0 \mathrm{~g}$ respectively, of crude extracts.

The bulk of the hexane extract $(60.0 \mathrm{~g})$ was chromatographed over silica gel under vacuum (VLC) and eluted with hexane, gradually increasing the polarity with ethyl acetate and then methanol. Twelve fractions were collected. Fraction $2(60.0 \mathrm{mg})$ was submitted to prep. TLC (silica gel), eluting with hexane-ethyl acetate 9:1 (v/v), to afford $16.0 \mathrm{mg}$ of lupeyl acetate. CC of fraction 10 (600.0 $\mathrm{mg}$ ) on silica gel (hexane, ethyl acetate and methanol in mixtures of increasing the polarity) followed by precipitation (methanol) of subfr. $10.13(45.0 \mathrm{mg})$ yielded $5.0 \mathrm{mg}$ of a mixture of $\beta$-sitosterol, campesterol and stigmasterol and $5.3 \mathrm{mg}$ of a mixture of $\beta$-sitosteryl glucopyranoside and stigmasteryl glucopyranoside.

The crude ethyl acetate and ethanol extracts were separately suspended in MeOH-H 20 19:1 (v/v). The solutions were partitioned first with hexane and then with dichloromethane. After evaporation at reduced pressure, the dichloromethane fractions were chromatographed separately on Si gel 60 (CC) with hexane and gradually increasing polarity, with ethyl acetate and then methanol. All fractions monitored by TLC.

From the dichloromethane fraction $(10.0 \mathrm{~g})$ of crude ethyl acetate extract, eleven fractions were collected. Fraction $3(45.0 \mathrm{mg})$ after prep. TLC (silica gel) eluting with dichloromethane, afforded $1.5 \mathrm{mg}$ of benzil 2,6dimethoxybenzoate. CC of fraction $6(1.04 \mathrm{~g})$ on silica gel (hexane, ethyl acetate and methanol in a mixture of increasing polarity), afforded 13 subfractions. Subfr. 6.4 yielded $100.0 \mathrm{mg}$ of $8 \beta$-hydroxyzaluzanin D (1).

From the dichloromethane extract $(2.0 \mathrm{~g})$ of crude $\mathrm{EtOH}$ extract, twelve fractions were collected. Fraction 6 (93.0 $\mathrm{mg}$ ) was submitted to prep. TLC (silica gel). Elution with hexane-dichloromethane $3: 2$ afforded $5.0 \mathrm{mg}$ of dehydrocostuslactone.

The hydroalcoholic extract $(2.0 \mathrm{~g})$ from the crude ethanol extract, soluble in methanol, was chromatographed on a Sephadex LH - 20 column using methanol as eluent, and twelve fractions were collected. Fraction 4 yielded 15.0 $\mathrm{mg}$ of luteolin and fraction 7 yielded $4.0 \mathrm{mg}$ of kaempferol.

$8 \beta$-hydroxyzaluzanin $D$ (1). Colorless gum; $\mathrm{C}_{17} \mathrm{H}_{20} \mathrm{O}_{5}$; IR $v_{\text {max }} \mathrm{cm}^{-1}$ (NaCl film): 3494 (OH alcohol), $1750(\gamma-$ lactone), 1730 (acetyl group), 1664 and 1641 (c=c double bonds); EI-MS, $\mathrm{m} / \mathrm{z}$ (relative intensity in \%): $262\left[\mathrm{M}^{+}\right.$ketene] (14), 91 (24), $43\left[\mathrm{CH}_{3} \mathrm{CO}\right]^{+}(100) ;{ }^{1} \mathrm{H}$ NMR (300 $\mathrm{MHz}, \mathrm{CDCl}_{3}$ ), see Table $1 .{ }^{13} \mathrm{C}$ NMR, DEPT $135^{\circ}$ and HMQC (75 MHz, $\mathrm{CDCl}_{3}$ ): 45.0 (d, C-1), 36.5 (t, C-2), 74.5 (d, C-3), 147.7 (s, C-4), 50.4 (d, C-5), 77.6 (d, C-6), 50.1 (d, C-7), 65.7 (d, C-8), 41.8 (t, C-9), 142.8 (s, C-10), 136.0 (s, C-11), 170.8 (s, C-12), 121.6 (t, C-13), 117.4 (t, C-14), 114.2 (t, C-15), 169.4 (s, C-1'), 21.2 (q, C-2').

\section{Results and Discussion}

The chromatographic fractionation of hexane, ethyl acetate and ethanol extracts yielded stigmasterol, $\beta$-sitosterol and campesterol, lupeyl acetate, ${ }^{21} \beta$-sitosteryl and stigmasteryl glucopyranosides ${ }^{22}$ benzil 2,6-dimethoxybenzoate, ${ }^{23}$ luteolin, ${ }^{24}$ kaempferol ${ }^{24}$ and dehydrocostuslactone. ${ }^{13,14}$ The structures were established by comparison of their spectroscopic properties (mainly IR, ${ }^{1} \mathrm{H}$ and ${ }^{13} \mathrm{C}$ NMR) with those reported in the literature and in some cases by direct comparison with authentic samples.

Structure of the guaianolide $\mathbf{1}$ was deduced from the IR, MS, ${ }^{13} \mathrm{C}$ and ${ }^{1} \mathrm{H}$ NMR spectra data and the stereochemistry was defined from the coupling constants' value $J$ and nOe difference correlations. This lactone has been previously reported as a synthetic compound obtained in the controlled acetylation of the natural guaianolide Integrifolin (8-epi-desacylcynaropicrin). ${ }^{12}$ The IR spectrum displayed bands at $1750 \mathrm{~cm}^{-1}$ ( $\gamma$-lactone), at $1730 \mathrm{~cm}^{-1}$ (acetyl group), at $3494 \mathrm{~cm}^{-1}$ (hydroxyl group) and weak bands at $1664,1641 \mathrm{~cm}^{-1}$ ( $\mathrm{c}=\mathrm{c}$ double bonds).

Inspection of the ${ }^{1} \mathrm{H}$ NMR spectrum of compound $\mathbf{1}$ indicated several signals very close to those observed in Zaluzanin $\mathrm{D}^{15}$. The position and the stereochemistry $(\beta$ orientation) of hydroxyl group at C-8 were determined by nOe correlation (Figure 1). nOe's were observed between the $\mathrm{H}-8(\delta 4.37)$ and $\mathrm{H}-13 \mathrm{a}(\delta 5.62), \mathrm{H}-7(\delta 2.98)$ and $\mathrm{H}-9 \mathrm{~b}$ $(\delta 2.61)$. In the same way, correlation of the H-3 ( $\delta 5.50)$ with $\mathrm{H}-2 \mathrm{~b}(\delta 2.45)$ and $\mathrm{H}-15 \mathrm{a}(\delta 5.32)$ in the nOe spectrum confirmed the $\alpha$-orientation of $\mathrm{H}-3$ which was attached to the carbon atom which is linked to the acetate group, as previously defined as Zaluzanin D (compound 2).

Just as the NMR spectrum of $\mathbf{2}$, the NMR spectrum of guaianolide $\mathbf{1}$ exhibited two characteristic doublets at $\delta$ 6.42 and 5.62 ( $J 3.8$ and $3.2 \mathrm{~Hz}$ respectively) corresponding to hydrogens of $\mathrm{H}-13 \mathrm{a}$ and $\mathrm{H}-13 \mathrm{~b}$ of an exocyclic methylene group conjugated with a $\gamma$-lactone. The exocyclic methylene groups attached to C-10 and C-4 were characterized by two singlets at $\delta 4.99(\mathrm{H}-14 \mathrm{a}), 5.10(\mathrm{H}-$ $14 \mathrm{~b})$ and a pair of triplets $(J 2.0 \mathrm{~Hz})$ at $\delta 5.32(\mathrm{H}-15 \mathrm{a})$ and $5.52(\mathrm{H}-15 \mathrm{~b})$, respectively. 


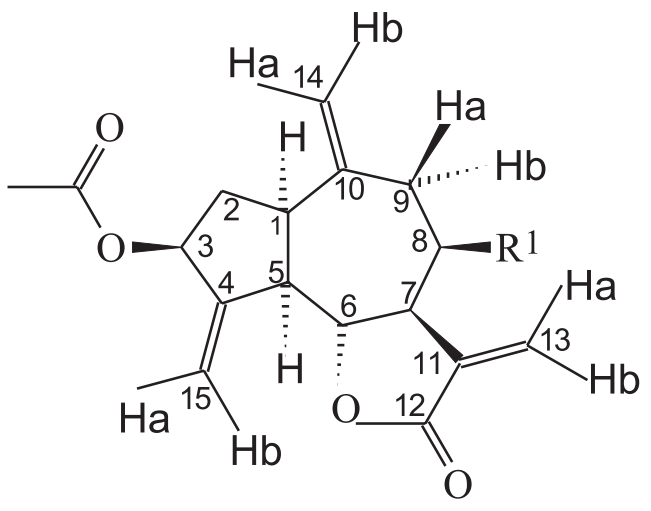

1: $\mathrm{R}^{1}=\mathrm{OH}$

2: $\mathrm{R}^{1}=\mathrm{H}$

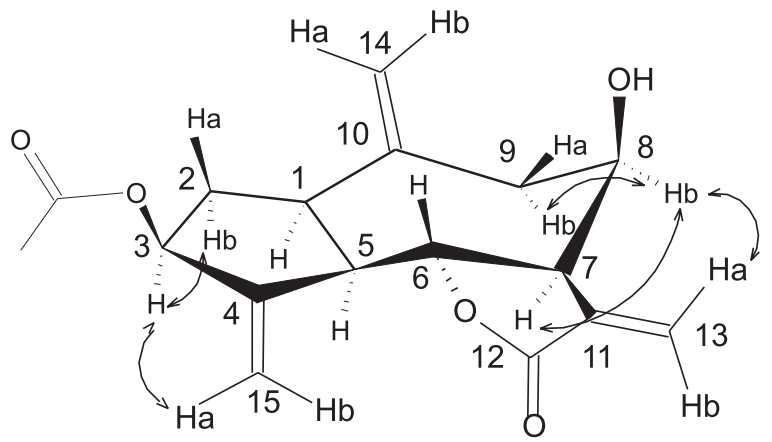

Figure 1. nOe correlations of compound $\mathbf{1 .}$

The stereochemistry cis of the ring junction at C-1 and C-5 was established by the coupling constant $(J 8.3 \mathrm{~Hz})$ between $\mathrm{H}-1$ and $\mathrm{H}-5$. In the case of $1 \beta, 5 \alpha$-transguaianolide, a value of $10.0 \mathrm{~Hz}$ or greater is expected according to that reported in the literature. ${ }^{25,26}$ The lactone ring junction was confirmed to be trans $(6 \beta \mathrm{H}, 7 \alpha \mathrm{H})$ by the large coupling constant $(J \sim 3.0 \mathrm{~Hz})$ of the $\mathrm{H}-13-\alpha$ methylene protons this is due to $\mathrm{H}-6 / \mathrm{H}-7(J 8.9 \mathrm{~Hz})$ coupling constant. ${ }^{16}$

All other signals were in agreement with the proposed structure of the guaianolide $\mathbf{1}$ (Table 1). Heteronuclear multiple quantum correlation ${ }^{1} \mathrm{H}-{ }^{13} \mathrm{C}$ (HMQC) allowed us to assign unambiguously the signals of all carbons.

Besides the importance chemosystematic, ${ }^{27}$ sesquiterpene lactone posseses a wide spectrum of biological activity. ${ }^{28}$ Zaluzanin C, Zaluzanin D and its derivatives
Table 1. ${ }^{1} \mathrm{H}$ NMR data $(\delta)$ for 1 at $300 \mathrm{MHz}$

\begin{tabular}{ll}
\hline $\mathbf{H}$ & $\mathbf{1}$ \\
\hline 1 & $2.95 \mathrm{td}(8.3,8.0 \mathrm{~Hz})^{\mathrm{a}}$ \\
$2 \mathrm{a}$ & $1.86 \mathrm{ddd}(14.0,8.0,6.3 \mathrm{~Hz})$ \\
$2 \mathrm{~b}$ & $2.45 \mathrm{ddd}(14.0,8.0,6.3 \mathrm{~Hz})$ \\
3 & $5.50 \mathrm{br} \mathrm{t}(6.3 \mathrm{~Hz})$ \\
5 & $2.82 \mathrm{dd}(10.0,8.3 \mathrm{~Hz})^{*}$ \\
6 & $4.47 \mathrm{dd}(10.0,8.9 \mathrm{~Hz})$ \\
7 & $2.98 \mathrm{br} \mathrm{d}(8.9 \mathrm{~Hz})$ \\
8 & $4.37 \mathrm{td}(5.6,2.7 \mathrm{~Hz})$ \\
$9 \mathrm{a}$ & $2.43 \mathrm{dd}(12.0,5.6 \mathrm{~Hz})$ \\
$9 \mathrm{~b}$ & $2.61 \mathrm{dd}(12.0,5.6 \mathrm{~Hz})$ \\
$13 \mathrm{a}$ & $5.62 \mathrm{~d}(3.2 \mathrm{~Hz})$ \\
$13 \mathrm{~b}$ & $6.42 \mathrm{~d}(3.2 \mathrm{~Hz})$ \\
$14 \mathrm{a}$ & $4.99 \mathrm{~s}$ \\
$14 \mathrm{~b}$ & $5.10 \mathrm{~s}$ \\
$15 \mathrm{a}$ & $5.32 \mathrm{t}(2.0 \mathrm{~Hz})$ \\
$15 \mathrm{~b}$ & $5.52 \mathrm{t}(2.0 \mathrm{~Hz})$ \\
2 & $2.10 \mathrm{~s}$ \\
\hline
\end{tabular}

a Signals attributed according spectrum in $\mathrm{C}_{5} \mathrm{D}_{5} \mathrm{~N}$.

have shown several biological activities, such as activity against the P 388 lymphocytic leukemia in vitro, ${ }^{29,30}$ antifungal activity, ${ }^{31,32}$ inhibitory activity on nitric oxide production and nuclear fator $\mathrm{KB},{ }^{33}$ inhibitory activity on ethanol absorption. ${ }^{34}$

On the basis of the above data, we conclude that $M$. hoehnei belongs to the Brazilian Mikania species groups, which produce sesquiterpene lactones. As other authors have also reported, ${ }^{4,11}$ we conclude after analysis of all this information that it is too early to establish correlations between the terpene chemistry and the morphology of this huge genus.

\section{Acknowledgements}

We thank Fundação de Amparo à Pesquisa do Estado de São Paulo (FAPESP) for financial aid and a fellowship to J. S. C., Professor Dr. Janie Garcia da Silva for plant identification and Professor Walter C. Holmes (Department of Biology, Baylor University, Waco, Texas) for information that he includes an M. hoehnei in the Mikania section. This study was supported by grants from CAPES, CNPq and FAPESP.

\section{References}

1. Barroso, G. M.; Arquivos do Jardim Botânico do Rio de Janeiro: Mikaniinae do Brasil, Rio de Janeiro: Jardim Botânico do Rio de Janeiro, 1958, p.333.

2. Robinson, B. L.; Contributions from the Gray Herbarium of Havard University: The Mikanias of Northern and Western South America, Havard: Cambridge Mass USA, 1934, vol. 104. 
3. Vilegas, W.; Roque, N. F.; Ferro, V.; Oliveira, F.; Cienc. Cult. 1984, 36, 530 .

4. Fabbri, H.; Oliveira, D. C. R.; Vichnewski, W.; Herz, W.; Biochem. System. Ecol. 1997, 25, 563.

5. Veneziani, R. C. S.; Camilo, D.; Oliveira, D. C. R.; Biochem. System. Ecol. 1999, 27, 99.

6. Nascimento, A. M.; Oliveira, D. C. R.; J. Braz. Chem. Soc. 2001, 12, 552.

7. King, R. M.; Robinson, H. In The Genera of the Eupatorieae (Asteraceae); King, R. M.; Robinson, H., eds.; Missouri Botanical Garden: St. Louis, 1987, p. 418, vol. 22.

8. Holmes, W. C. In Advances in Compositae Systematics; Hind, D. J. N.; Jeffrey, C.; Pope, G.V., eds.; Royal Botanical Gardens: Kew, 1995, p. 239.

9. Holmes, W. C. In Compositae: Systematics, Proceedings of the International Compositae Conference 1994; Hind, D. J. N.; Beentje, H. J., eds.; Royal Botanical Gardens: Kew, 1996, p. 621, vol. 1 .

10. Herz, W. In New Trends in Natural Products Chemistry; Rahman, Atta-ur-; Le Quesne, P. W., eds.; Elsevier Science Publishers B. V.: Amsterdam, 1986, p. 143.

11. Herz, W.; J. Indian Chem. Soc. 1998, 75, 559.

12. Massanet, G. M.; Collado, I.G.; Macias, F. A.; Luis F. R.; Vergara, C.; Phytochemistry 1984, 23, 912.

13. Mathur, S. B.; Hiremath, S. V.; Kulkarni, G. H.; Kelkar, G. R.; Bhattacharyya, S. C.; Simonovic, D.; Rao, A. S.; Tetrahedron 1965, 21, 3575 .

14. Neves, M.; Morais, R.; Gafner, S.; Stoeckli-Evans, H.; Hostettmann, K.; Phytochemistry 1999, 50, 967.

15. Ando, M.; Kusaka, H.; Ohara, H.; Takase, K.; Yamaoka, H.; Yanagi, Y.; J. Org. Chem. 1989, 54, 1952.

16. De Vivar, A. R.; Cabrera, A.; Ortega, A.; Romo, J.; Tetrahedron 1967, 23, 3903.

17. Yoshioka, H.; Mabry, T. J.; Timmermann, B. N. ; Sesquiterpene Lactones Chemistry, NMR and Plant Distribution; University of Tokyo Press: Japan, 1973, p. 336.
18. Castro, V.; Jakupovic, J.; Bohlmann, F.; Phytochemistry 1986, 25,1750

19. Cuenca, M. D.; Borkosky, S.; Catalán, C. A. N.; Díaz, J. G.; Herz, W.; Phytochemistry 1992, 31, 3521.

20. Bardón, A.; Cardona, L.; Catalán, C. A. N.; Pedro, J. R.; Phytochemistry 1996, 41, 845.

21. Olea, R. S. G.; Roque, N. F.; Quim. Nova 1990, 13, 278

22. Kojima, H.; Sato, N.; Hatano, A.; Ogura, H.; Phytochemistry 1990, 29, 2351.

23. Rodrigues, D. C.; Yoshida, M.; Gottlieb, O. R.; Phytochemistry 1992, 31, 271.

24. Markhan, K. R.; Geiger, H. In The Flavonoids; Harbone, J. B., ed.; Chapman and Hall: London, 1994, p. 450.

25. Merfort, I.; Willuhn, G.; Wendisch, D.; Gondol, D.; Phytochemistry 1996, 42, 1093.

26. Zdero, C.; Bohlmann, F.; King, R. M.; Robinson, H.; Phytochemistry 1987, 26, 1207.

27. Emerenciano, V. D. P.; Ferreira, Z. S.; Kaplan, M. A. C.; Gottlieb, O. R.; Phytochemistry 1987, 26, 3103.

28. Pickman, A. K.; Biochem. System. Ecol. 1986, 14, 255.

29. Jolad, S. D.; Wiedhopf, R. M.; Cole, J. R.; J. Pharm. Sci. 1974, 63, 1321

30. Asakawa, Y.; Takemoto, T.; Phytochemistry 1979, 18, 285.

31. Vajs, V.; Todorovíc, N.; Ristíc, M.; Tesevíc, V.; Todorovíc, B.; Janáckovic, P.; Marin, P.; Milosavlijevíc, S.; Phytochemistry 1999, 52, 383.

32. Santamaría, F.; Zaera, E.; Vásquez, D. Jiménez, A.; Biochem. Biophys. Res. Commun. 1984, 123, 59.

33. Matsuda, H.; Kagerura, T.; Toguchida, I.; Ueda, H.; Morikawa, T.; Yoshikawa, M.; Life Sci. 2000, 66, 2151.

34. Yoshikawa, M.; Shimoda, H.; Uemura T.; Morikawa, T, Kawahara, Y. Matsuda, H.; Bioorg. Med. Chem. 2000, 8, 2071.

Received: May 15, 2002

Published on the web: July 29, 2003

FAPESP helped in meeting the publication costs of this article. 